\title{
What Is a Healthy Dating or Marriage Relationship?'1
}

\author{
Victor W. Harris²
}

The American author Mignon McLaughlin insightfully stated that "a successful marriage requires falling in love many times, always with the same person." Successful marriages can provide many benefits, including increased economic, physical, mental, and emotional well-being (Institute for American Values, 2002).

Conversely, there are significant potential costs associated with divorce, such as stress, depression, and economic insecurity (Schramm, 2009). High divorce rates may reflect a growing emphasis on personal freedom and self-fulfillment and a dwindling commitment to long-term relationships. Divorce rates may also reflect that marriage is currently viewed as more of a self-actualizing experience with greater expectations for creating and maintaining satisfying relationships (Bianchi \& Casper, 2000; Maslow, 1968).

Healthy relationships developed during childhood, adolescence, and early adulthood can provide the building blocks for healthy adult marriage relationships. Approximately $90 \%$ of Americans will marry at some point in their lives, so it's worth the investment of time and effort to build a healthy dating relationship and eventual marriage (Bianchi \& Casper, 2000).

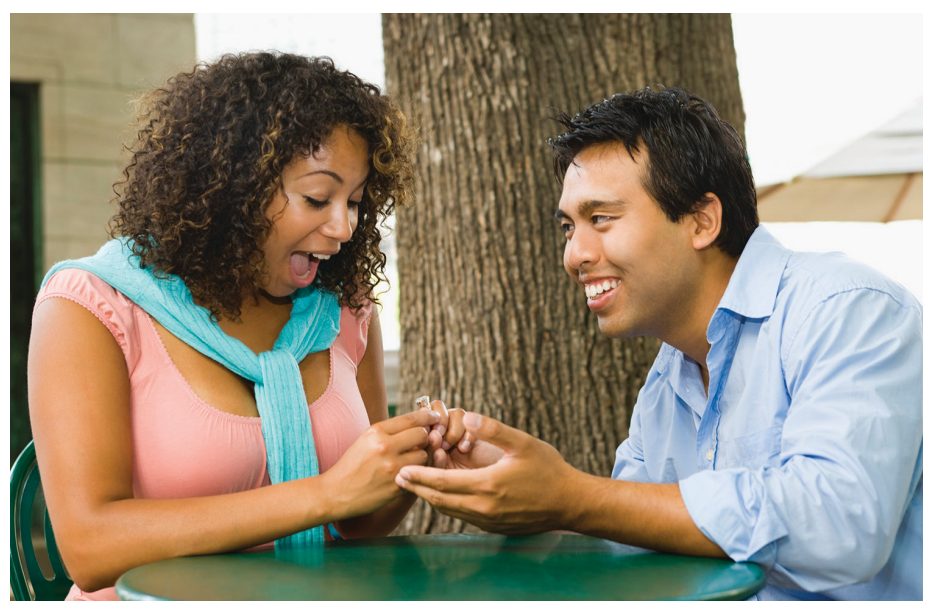

Figure 1. The majority of Americans will marry at some point in their lives, making it important to understand what a healthy dating and marriage relationship is.

Credit: Creatas Images

\section{Helpful Information}

\section{Defining a Healthy Romantic Relationship}

Defining what a healthy romantic relationship is can be challenging. Thankfully, modern research has given us a good idea of what healthy dating and marriage relationships look like. Take a minute and review the definitions below and determine if they capture what a healthy relationship looks like to you. Then answer the questions in the next section to get an idea of the strengths already present in your relationship and those things you may want to work on.

- Healthy Marriage - A stable and satisfying marriage relationship built upon a strong friendship that is safe,

1. This document is FCS2323, one of a series of the Department of Family, Youth and Community Sciences, Florida Cooperative Extension Service, Institute of Food and Agricultural Sciences, University of Florida. Original publication date March 2013. Visit the EDIS website at http://edis.ifas.ufl.edu.

2. Victor W. Harris, assistant professor, Department of Family, Youth and Community Sciences; Florida Cooperative Extension Service, Institute of Food and Agricultural Sciences, University of Florida, Gainesville, FL 32611. 
secure, loving, passionate, committed, respectful, and trusting, characterized by an ability to negotiate differences and resolve conflict, with the absence of domestic violence (Harris et al., 2008).

- Healthy Dating - A stable and satisfying relationship built upon varying levels of friendship, safety, security, love, passion, commitment, respect, and trust, characterized by an ability to negotiate differences and resolve conflict, with the absence of domestic violence (Harris et al., 2008).

- Marital/Relationship Quality - A subjective perceptual evaluation of the strength of a couple's friendship (Larson \& Holman, 1994; Johnson et al., 2002; Schramm, Marshall, Harris, \& George, 2003).

- Marital/Relationship Stability - A subjective perceptual evaluation of whether or not the marriage or relationship will remain intact or dissolve (Larson \& Holman, 1994; Johnson et al., 2002; Schramm, Marshall, Harris, \& George, 2003).

- Marital/Relationship Satisfaction - A subjective perceptual evaluation of levels of well-being (satisfaction and happiness) in a couple's relationship or marriage (Larson \& Holman, 1994; Johnson et al., 2002; Schramm, Marshall, Harris, \& George, 2003).

\section{Things You Can Use}

You can easily assess how healthy your dating or marriage relationship is by taking the following brief survey:

1. Is my dating/marriage relationship stable (not likely to dissolve)?

2. Am I generally satisfied and happy with my dating/ marriage relationship?

3. Do we have a strong friendship?

4. Do I feel safe with this person?

5. Does this person help me feel secure in who I am and in our relationship?

6. Is there a lot of love expressed in our relationship?

7. Does passion play a role in our relationship?

8. Are we committed to each other and our relationship for the long-term?
9. Do we consistently show each other respect?

10. Can we trust each other?

a. Can we depend on each other?

b. Are we available for each other?

c. Are we responsive and supportive of each other?

d. Do we resolve differences and conflict in a constructive manner?

e. Do we have a positive view of the future of the relationship?

11.Is any kind of psychological, sexual, or physical abuse present in our relationship?

Score your survey by counting the number of "Yes" and "No" answers. These questions reflect significant areas of relationship health and development. If you answered "No" to more than one question, with the exception of number 11, you may want to seek help from reputable sources, such as books, websites, workshops, a pastor, or a marriage therapist. A "Yes" answer to question 11 is an indicator that your marriage relationship is not healthy and you need assistance right away. A good starting point for finding help is your local domestic violence/abuse shelter and/or a qualified therapist (you may be able to find one using http://www.therapistlocator.net).

Developing and maintaining healthy dating relationships can lead to developing and maintaining healthy marriage relationships. Understanding what healthy romantic relationships look like is a critical first step toward being able to enjoy the benefits of quality, stable, and satisfying marriage relationships.

\section{References}

Bianchi, S. M., \& Casper, L. M. (Eds.). (2000). American families. Population Bulletin, 55(4), 1-43. Washington, D.C.: Population Reference Bureau.

Harris, S. M., Glenn, N. D, Rappleyea, D. L., Diaz-Loving, R., Hawkins, A. J., Daire, A. P., Osborne, C., \& Huston, T. L. (2008). Twogether in Texas: Baseline report on marriage in the Lone Star State, p. 5. Austin, TX: Health and Human Services Commission.

Institute for American Values. (2002). Why marriage matters: Twenty-one conclusions from the social sciences. New York: Institute for American Values. 
Johnson, C. A., Stanley, S. M., Glenn, N. D., Amato, P. R., Nock, S. L., Markman, H. J., \& Dion, M. R. (2002). Marriage in Oklahoma: 2001 baseline statewide survey on marriage and divorce (S02096OKDHS). Oklahoma City, OK: Department of Human Services.

Larson, J. H., \& Holman, T. B. (1994). Predictors of marital quality and stability. Family Relations 43(2), 228-237.

Maslow, A. H. (1968). Toward a psychology of being $\left(2^{\text {nd }}\right.$ ed.). Princeton, NJ: Van Nostrand.

Schramm, D. G. (2009). Counting the cost of divorce: What those who know better rarely acknowledge. The Family in America: A Journal of Public Policy, 23(3), 55-56.

Schramm, D. G., Marshall, J. P., Harris, V. W., \& George, A. (2003). Marriage in Utah: 2003 baseline statewide survey on marriage and divorce. Salt Lake City: Utah Department of Workforce Services. 